\title{
MASTER
}

\section{THERMISTORIZED EBULLIOMETRY SYSTEM FOR DETERMINING MOLECULAR WEIGHTS OF FLUOROCARBONS}

\author{
AUTHORS:
}
R. D. Rivers
W. O. Gentry
C. A. Kienberger

OAK RIDGE GASEOUS DIFFUSION PLANT OAK RIDGE Y.12 PLANT
- OAK RIDGE NATIONAL LABORATORY

- PADUCAH gaSEOUS DIFFusION PLANT 


\section{DISCLAIMER}

This report was prepared as an account of work sponsored by an agency of the United States Government. Neither the United States Government nor any agency Thereof, nor any of their employees, makes any warranty, express or implied, or assumes any legal liability or responsibility for the accuracy, completeness, or usefulness of any information, apparatus, product, or process disclosed, or represents that its use would not infringe privately owned rights. Reference herein to any specific commercial product, process, or service by trade name, trademark, manufacturer, or otherwise does not necessarily constitute or imply its endorsement, recommendation, or favoring by the United States Government or any agency thereof. The views and opinions of authors expressed herein do not necessarily state or reflect those of the United States Government or any agency thereof. 


\section{DISCLAIMER}

Portions of this document may be illegible in electronic image products. Images are produced from the best available original document. 
Printed in the United States of America. Avnilable from Clearinghouse for Federal Scientific and Technical Information, National Bureau of Standards,

U.S. Department of Commerce, Springfield, Virginia 22151

Price: Printed Copy $\$ 3.00$; Microfiche $\$ 0.65$

\section{LEGAL NOTICE}

This repurt was prepared as an account of Government sponsored work. Neither the United States, nor the Commission, nor any person acting on behalf of the Commission:

A. Makes any warranty or representation, expressed or implied, with respect to the accuracy, completeness, or usefulness of the information contained in this report, or that the use of any information, apparatus, method, or process disclosed in this report may not infringe privately owned rights; or

B. Assumes any liabilities with respect to the use of, or for damages resulting from the use of any information, apparatus, method, or process disclosed in this report.

As used in the above, "person acting on behalf of the Cnmmirsion" includes dny employee or rantractur uf ilie Commission, or employee of such contractor, to the extent that such employee or contractor of the Commission, or employee of such contractor prepares, disseminates, or provides access to, any information pursuant to his employment or contract with the Commission, or his employment with such contractor. 
Date of Issue: July 17, 1967

Report Number: K-1690

Subject Category: CHEMISTRY

CEBTI RTICSS

H.c. 3.00

65

THERMISTORIZED EBULLIOMETRY SYSTEM FOR DETERMINING MOLECULAR WEIGHTS OF FLUOROCARBONS

R. D. Rivers

W. O. Gentry

C. A. Kienberger

Tcchnical Division

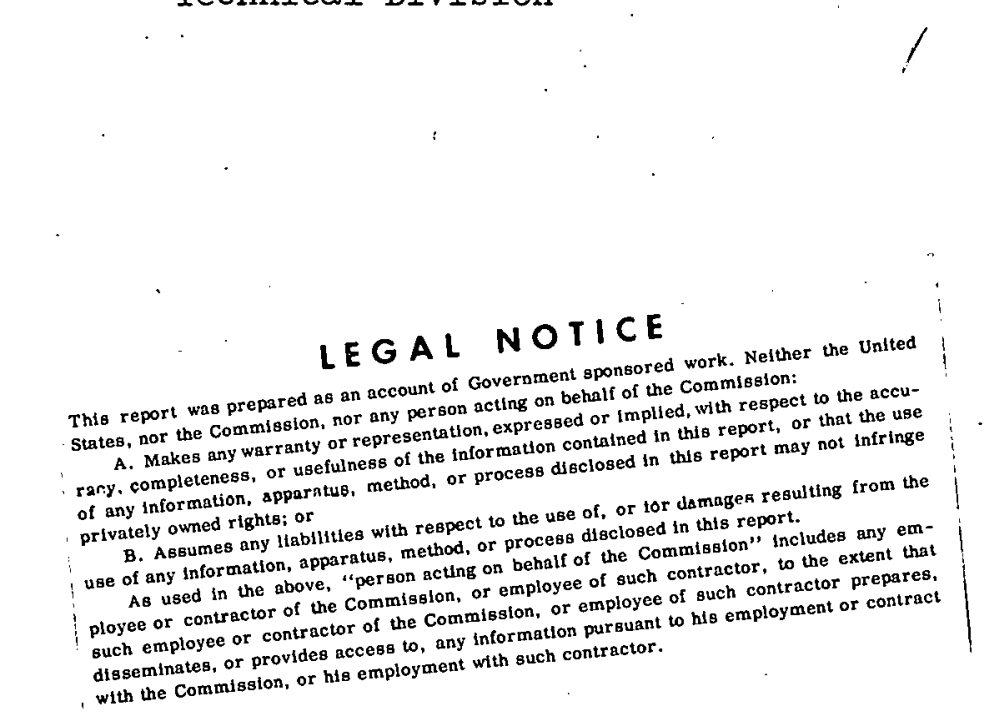

UNION CARBIDE CORPORATION

NUCLEAR DIVISION

Oak Ridge Gaseous D1ffusion Plant

Oak Ridge, Tennessee 


\section{THPS PAGE}

\section{WAS INTENTIONALLY \\ LEFT BLANK}


Report Number: $\mathrm{K}-1690$

Subject Category: CHEMISTRY

Title: THERMISTORIZED EBULLIOMETRY SYSTEM FOR DETERMINING MOLECULAR WEIGHTS OF FLUOROCARBONS

Authors: R. D. Rivers, W. O. Gentry, and C. A. Kienberger

$\underline{A} \underline{B} \underline{S} \underline{\underline{T}} \underline{R} \underline{A} \underline{C} \underline{T}$.

A thermistorized ebulliometry system has been devised, constructed, and calibrated for making molecular weight measurements of fluorocarbon compounds, using Freon-113 as the solvent. The system consisted of a glass probe containing thermistors encased in epoxy resin, a commercially fabricated vacuum-jacketed ebulliometer, a bridge.circuit, and an electronic galvanometer. The ebulliometry system was thermally insulated with plastic foam and shielded with an electrically grounded aluminum case.

The thermal noise background of the new system limited the temperature readability to $\pm 0.00035^{\circ} \mathrm{C}$, approximately one-tenth that of a former thermometer ebulliometry system. This decrease in noise background, when applied to molecular weight measurements, represents a corresponding improvement in precision of about tenfold over previous molecular weight measurements in the range of 1000 to 1200. The absolute standard deviation of a single molecular weight measurement in this range is \pm 8 mol. wt units for the new system. 


\section{THIS PAGE}

WAS INTENTIONALLY

LEFT BLANK 
THERMISTORIZED EBULLIOMETRY SYSTEM FOR DETERMINING MÓLECULAR WEIGHTS OF FLUOROCARBONS

CONTENTS

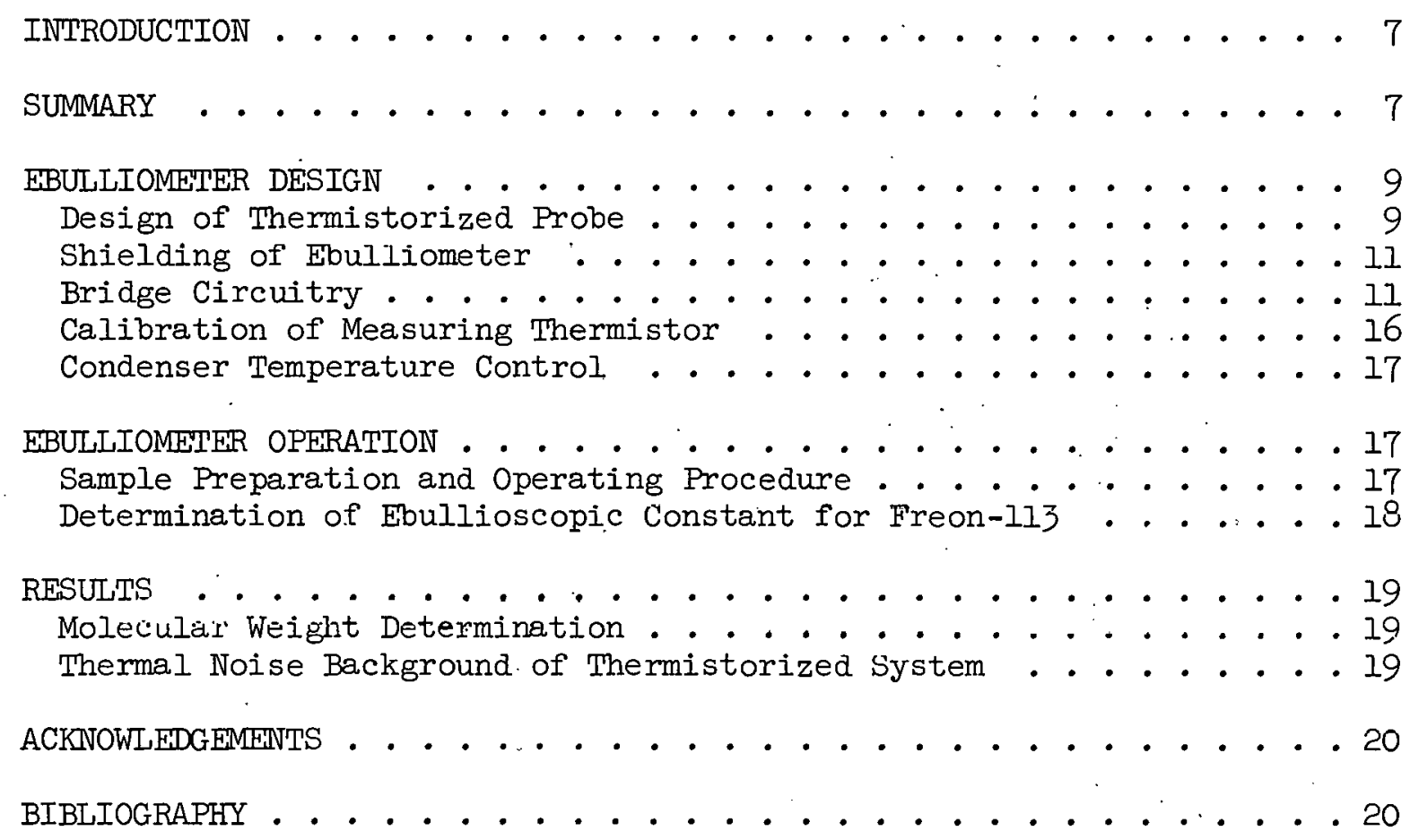




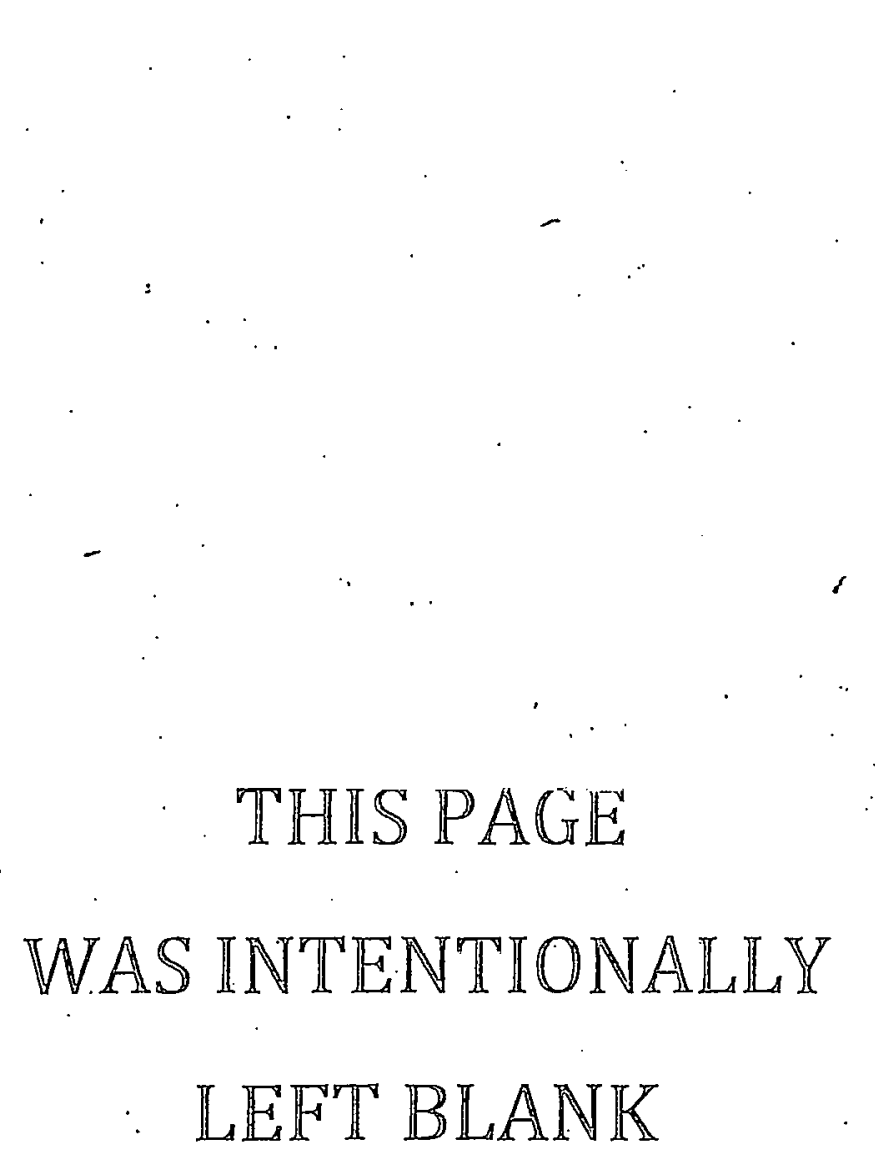


THERMISTORIZED EBULLIOMETRY SYSTEM FOR

DETERMINING MOLECULAR WEIGHTS OF FLUOROCARBONS

A precise and accurate method was needed for determining the molecular weights of fluorocarbon compounds being prepared, studied, and characterized by the Development Departments of the Oak Ridge Gaseous Diffusion Plant. The ebulliometry method of measuring the difference in boiling points between a solution and a pure solvent, at the same pressure, is considered a reliable approach to such measurements. The ebulliometer, basically sketched in figure 1 , measures the difference in temperature (elevation of the boiling point) between the boiling point of the solution (solute and solvent) and the pure solvent. The boiling point of the solution is obtained as it is circulated with the Cottrell pump over the temperature sensor. The boiling point of the "pure" solvent is simultaneously measured by the sensor in the vapor above the solution. (With adequate difference in vapor pressure of solvent and solute, and with dilute solutions, the vapor is essentially pure solvent.) The molecular weight of the solute is calculated from the elevation of the boiling point $(\Delta \mathrm{T})$ as discussed later.

Imprecise molecular weights of fluorocarbons were previously obtained in the Laboratory using a commercial vacuum-jacketed ebulliometer, fitted with a differential water thermometer. The imprecision of the former ebulliometer system was attributed to poor sensitivity and readability of the thermometer and to thermal conditions which affected the thermometer. The thermal noise background of the thermometer was caused by the superheating of the boiling solution, and by thermal gradients that developed in the system due to temperature variation in the water feeding the condenser and in the atmosphere surrounding the system.

Considerable improvement in the commercial ebulliometry system was necessary to provide reliable molecular weight measurements of fluorocarbon compounds in the range of 1000 to 1200 . A more stable and sensitive method had to be developed for measuring the temperature differential between the boiling point of the solution and the pure solvent. Thermistors, as suggested by Blackmore (1), were adapted, optimized, and used in place of the thermometer for measuring the differential temperature in the ebulliometry system. The thermal background of the thermistorized system was stabilized by 1 ) optimizing the heat capacities of the thermistors, 2) insulating the ebulliometry system, and 3) controlling the temperature of the cooling water for the condenser. These modifications and improvements resulted in the development of a thermistorized ebulliometry system that is stable and sensitive for measuring the molecular weights of fluorocarbons in Freon-113 solutions.

\section{SUMMARY}

An improved ebulliometry system has been devised, constructed; and calibrated for making molecular weight measurements of fluorocarbon compounds, using Freon-7.1.3 as the solvent. This report describes the development and fabrication of a thermistorized probe and bridge circuitry, the 


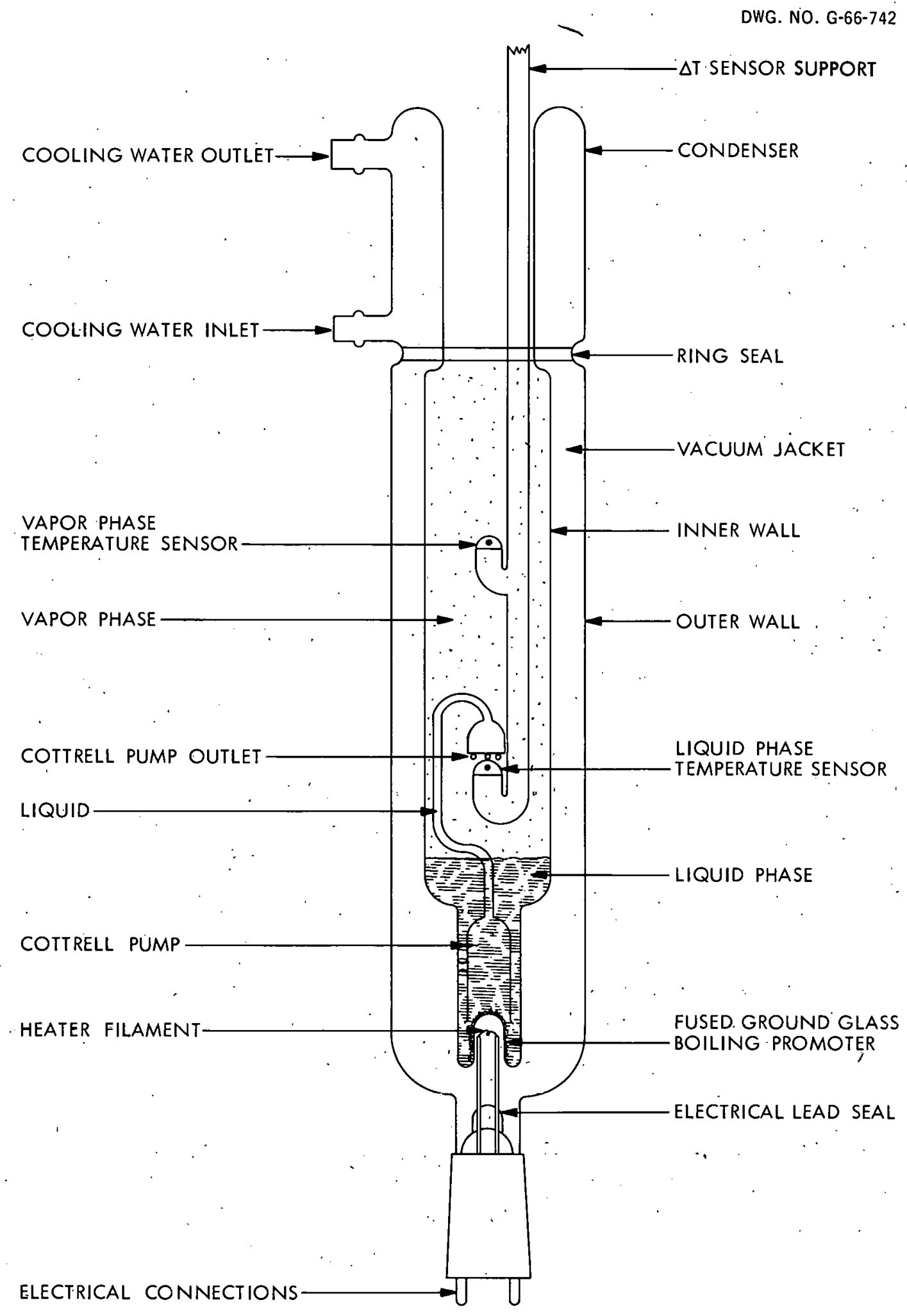

Figure 1. 
insulation and shielding of the ebulliometer, and the operation of the ebulliometry system. Methods are described for calibrating the solutionmeasuring thermistor and for determining its thermal coefficient of resistance. The thermal noise background and the precision of the results from the new ebulliometry system are compared with those obtained earlier from a thermometer ebulliometry system. The ebullioscopic constant is determined for the solvent Freon-113 in the new system.

\section{EBULLIOMETER DESIGN}

Design of Thermistorized Probe

The water thermometer was removed from a commercial ebulliometer; a thermistorized probe was designed for use in its place. The initial probe was fabricated from fluorothene and Teflon to eliminate corrosion. Because it was not mechanically firm, it was later replaced with a glass one which was easy to remove and return to the ebulliometer without changing the original position of the thermistors in the system.

The thermistors (type 32Al, Victory Engineering Corporation, Union, N. J.) consisted of tiny beads with electrical leads sealed in solid glass rod supports. The electrical rcsistance of six thermistors was measured, and two thermistors having about equal (less than 1 percent difference) or "matched" resistances were selected. The matched pair has a thermal time response of 25 seconds. This pair of thermistors was connected into an appropriate bridge circuit to permit development of a temperature probe system.

The first probe designed is shown in figure 2. The electrical leads of the measuring thermistor, located in the lower position (solution stream), were placed in a U-bent fluorothene plastic tube which served as the main probe support. The electrical leads of the top (reference) thermistor were placed in a Teflon tube which was clamped onto the end of a vertical Teflon covered metal rod used for raising and lowering the thermistor. The rod was attached to the probe with sliding clamps, allowing it to muve vertically. This design was adjustable and helped in locating the reference thermistor in the best position for thermal stabilily.

The plastic probe was inserted into the ebulliometer in place of the water thermometer. The lower (measuring) thermistor was positioned in the solution stream at the exit of the Cottrell pump in the ebulliometer, figure 1 , and the top (reference) thermistor was placed about $6-1 / 2 \mathrm{~cm}$ above it, in the vapor phase. The sensitive ends of the thermistors were exposed directly to the liquid and vapor phases. This probe was satisfactory; but, since the fluorothenc was slightly flexible, it was rather difficult to return the thermistors to their exact original positions, once the probe was moved.

A more rigid probe was needed, for assurance that the thermistors would be returned to their original positions in the ebulliometer whenever the 


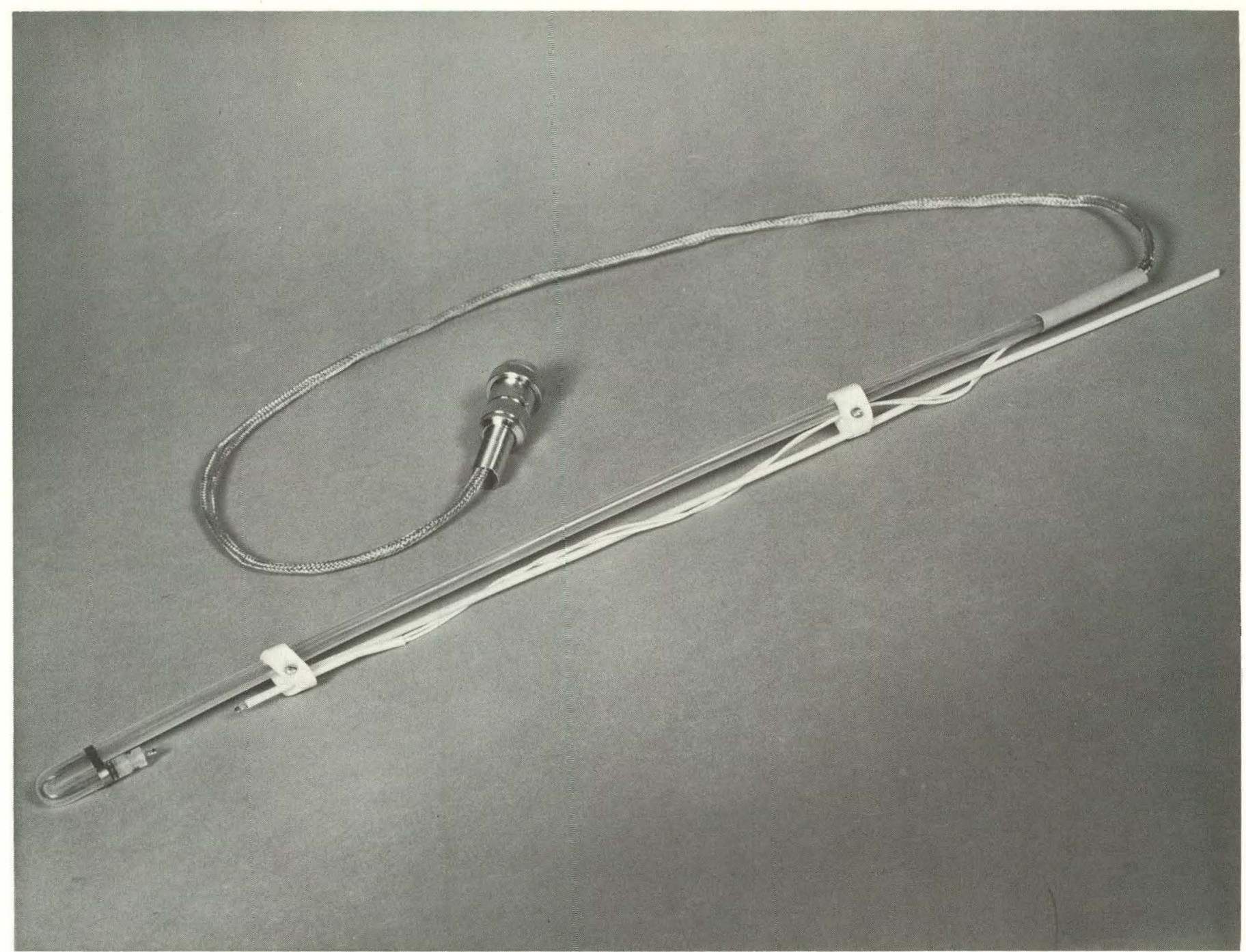

Figure 2

THERMISTORIZED FLUOROTHENE PROBE 
probe was installed. (The probe needed to be removed each time fresh solvent or a sample was added to the ebulliometer.) The fluorothene tube was replaced with a glass tube approximately 18 inches long and 0.25 inch in diameter. The glass probe is shown installed in figure 3 and alone in figure 4. In this design, both sensors were positioned in upward-pointed arms, eliminating possible contact by condensate which might fall downward on the probe.

In the new probe, the thermistors were encased in caps of epoxy resin (Hysol resin, Hysol Corporation, Olean, N. J.), as shown in figure 4. Fluctuation of the thermal noise background of the earlier thermistorized system appeared to be due to variations in the flow of the solution stream, probably permitting intermittent exposure of the measuring (solution) thermistor to vapors. This variation in background decreased considerably when the sensitive ends of the thermistors were encased. This housing provided thermal lag (via heat capacity) which minimized effects of rapid variations, giving an average measurement.

\section{Shielding of Ebulliometer}

The ebulliometer was thermally insulated with plastic foam to protect the thermistors from external heat sources and drafts. Undesirable static charges, generated by the plastic, were minimized by covering the plastic with a grounded aluminum box, shown in figure 3. A window, shown covered, is provided for viewing the thermistors.

\section{Bridge Circuitry}

The electrical circuit was basically a simple wheatstone bridge arrangement, shown in figure 5, with the thermistors used as the temperature sensing elements in two arms of the bridge. The other two arms of the bridge were composed of fixed wire-wound resistors and a "zero adjust." A group of ten 1000-ohm resistors was installed in each of the two fixed arms of the bridge, to provide for matching the fixed arms with the thermistors used. The 25-ohm 10-turn measuring potentiometer, connected in series with the measuring thermistor, gave a reading sensitivity of $0.025 \mathrm{ohms}$ for one divisiun of the dial. This potentiometer measured the change in resistance required to balance the bridge when the liermistor in the liquid phase (solution) was subjected to a higher temperature than that of boiling (pure) solvent. This change in resistance represented the difference in temperature betwcen the two thermistors.

An electronic galvanometer (Electronik, Minneapolis-Honeywell Regulator Company, Philadelphia, Ha.) pruvided a very sensitive null detector for halancing the Wheatstone bridge circuit. The bridge is installed in a case along with a compact power supply (see figure 6). The power for the bridge circuit was furnished by a solid state power supply (Weston D-Tax) which delivered $1.0444 \pm 0.0005$ volts to a load of approximately 100 ohms . The load requirement for proper operation was obtained by connecting 100 ohms of resistance in parallel with the bridge components (figure 5, left). The 100-ohm load also served as a voltage divider, from which the desired 
РНОTO NO. PH-66-374

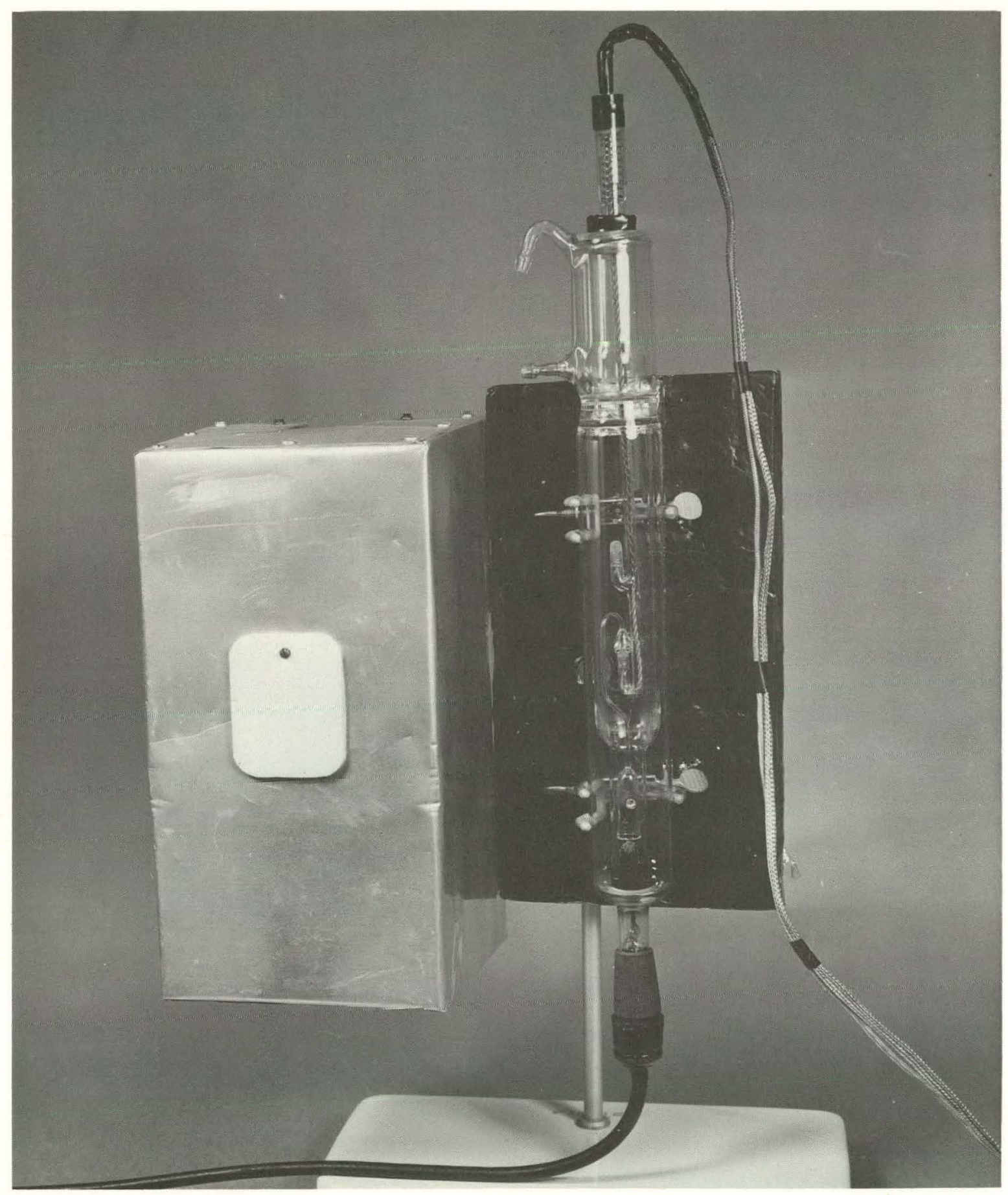

Figure 3

THERMISTORIZED EBULLIOMETRY SYSTEM 


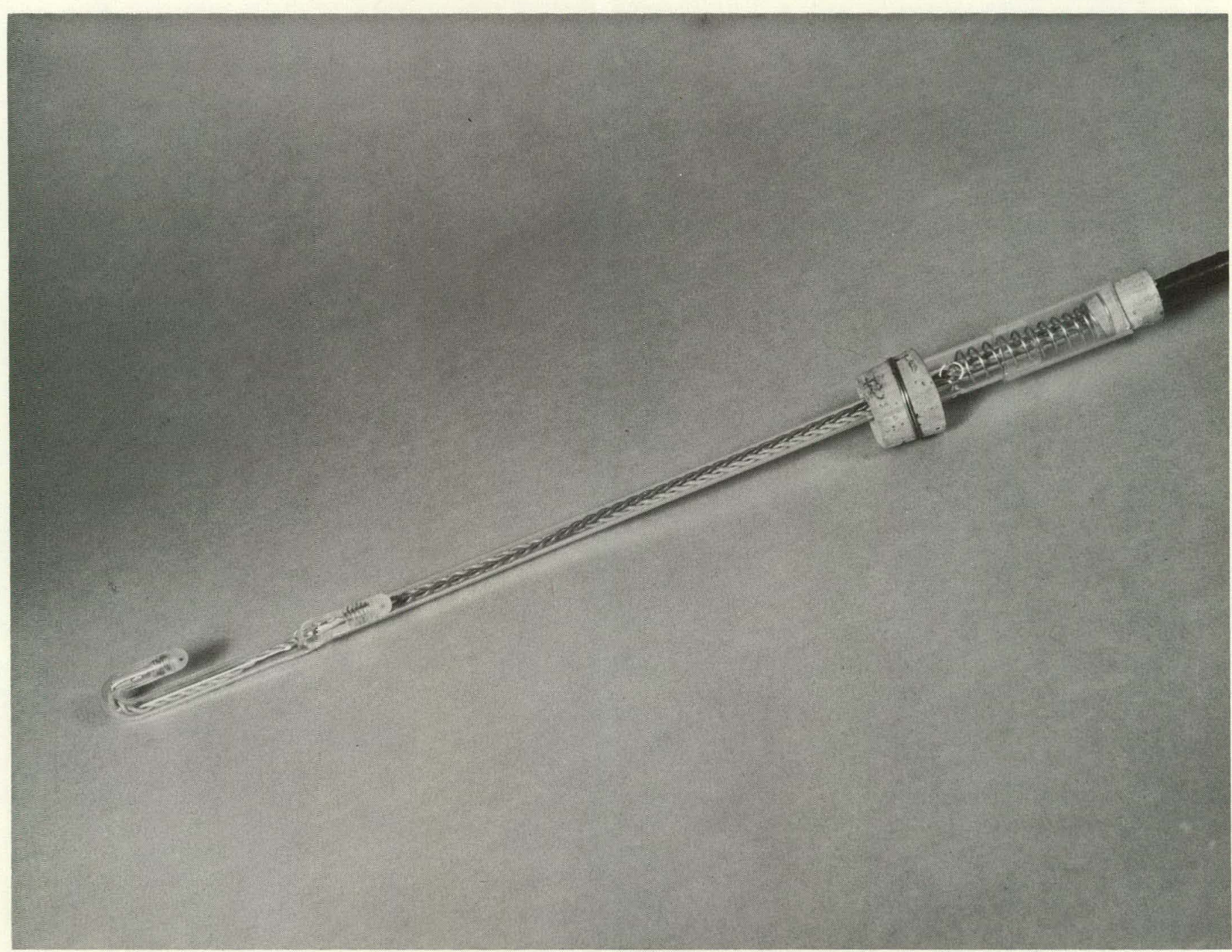

Figure 4

THERMISTORIZED GLASS PROBE 


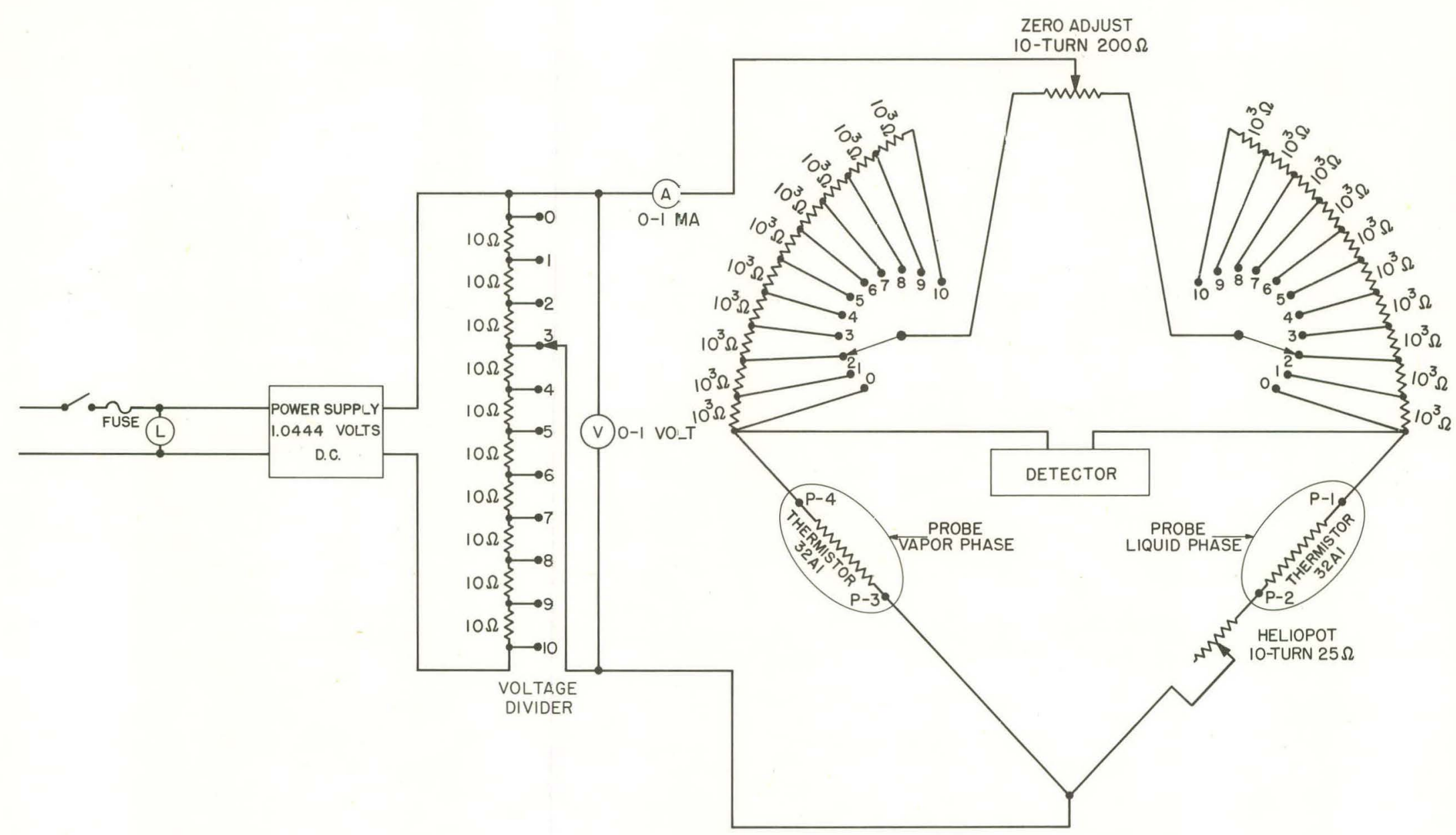

Figure 5

THERMISTORIZED BRIDGE CIRCUIT FOR EBULLIOMETRY 


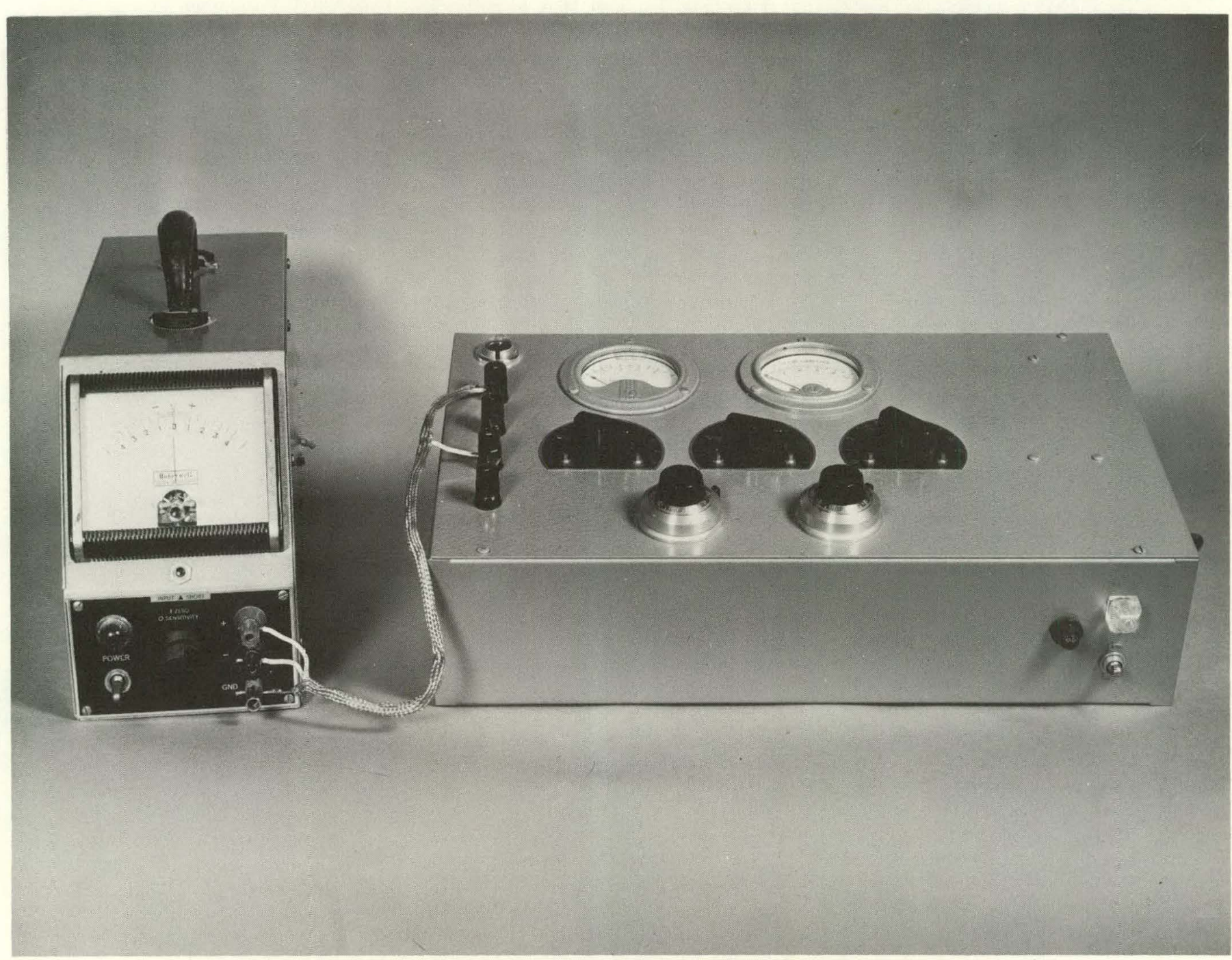

Figure 6

ELECTRONIC GALVANOMETER, POWER SUPPLY, AND BRIDGE 
bridge voltage was obtained. The bridge voltage and current were selected so that the power dissipated by either thermistor was less than one milliwatt. Low power dissipation is a requirement for sensitive temperature detection.

Calibration of Measuring Thermistor

The lower thermistor, used to measure the temperature of the solution, was calibrated in a temperature-controlled oil bath normally used for calibrating thermocouples. The bath temperature was measured with a platinum resistance thermometer which had been calibrated at the National Bureau of Standards and was controlled with an automatic temperature-recording Mueller bridge. Temperature changes of $\pm 0.0003^{\circ} \mathrm{C}$. could be detected with this equipment. The resistance of the measuring thermistor was determined by connecting it in series with a standard 10,000 ( \pm 0.1 ) ohm resistor and a battery, and measuring the voltage across the standard and the thermistor with a digital voltmeter. The flow of current, table I, through the thermistor was calculated from the voltage measured across the standard resistor using Ohrr's Law. With the known flow of current through the thermistor and the measured voltage across it, the resistance of the thermistor was determined.

The resistance of the measuring thermistor was determined at several bath temperatures, and the thermal coefficient of resistance was calculated. This calibration constant, $30.60 \mathrm{ohms} /{ }^{\mathrm{C}} \mathrm{C}$. or (more convenient) $0.03268^{\circ} \mathrm{C} . / \mathrm{ohm}$, was then applicable for converting resistance differences to temperature differences in the ebulliometer.

\section{TABLE I}

CALIBRATION DATA FOR THE MFASURING THERMISTOR

\begin{tabular}{|c|c|c|c|c|c|}
\hline $\begin{array}{c}\text { Tempera- } \\
\text { ture, } \\
{ }_{\mathrm{C} .} .\end{array}$ & $\begin{array}{l}\text { Voltage } \\
\text { Across } \\
\text { 10,000 ohm } \\
\text { Resistor, } \\
\text { volts } \\
\end{array}$ & $\begin{array}{l}\text { Current } \\
\text { Through } \\
\text { Thermistor, } \\
\text { amp. } \\
\end{array}$ & $\begin{array}{c}\text { Voltage } \\
\text { Across } \\
\text { Thermistor, } \\
\text { volts } \\
\end{array}$ & $\begin{array}{l}\text { Resistance } \\
\text { of } \\
\text { Thermistor, } \\
\text { ohms } \\
\end{array}$ & $\begin{array}{l}\text { Thermal Co- } \\
\text { efficient of } \\
\text { Resistance of } \\
\text { Thermistor, } \\
\text { ohms/ }{ }^{0} \mathrm{C} \text {. }\end{array}$ \\
\hline 48.895 & 2.485 & $2485 \times 10^{-7}$ & 0.2120 & 853.12 & \multirow{3}{*}{30.67} \\
\hline 48.287 & 2.480 & 2480 & 0.2162 & 871.77 & \\
\hline 47.878 & 2.477 & 2477 & 0.2190 & 884.13 & \\
\hline 47.550 & 2.474 & 2474 & 0.2212 & 894.09 & 30.37 \\
\hline 47.161 & 2.473 & 2473 & 0.2240 & 905.78 & \multirow{2}{*}{31.71} \\
\hline 46.693 & 2.469 & 2469 & 0.2273 & 920.62 & \\
\hline * Calibr & on consta & $=0.03268$ & /ohm. & \multicolumn{2}{|c|}{ Mean $=\overline{30.60 *}$} \\
\hline
\end{tabular}




\section{Condenser Temperature Control}

In the early development work, the ebulliometer condenser was cooled with tap water. The temperature of the water fluctuated 3 or $4^{\circ} \mathrm{C}$. during the day (8-hour period). A water temperature increase was followed by an increase in the temperature of the solvent vapors, causing a drift in the apparent boiling point of the solvent, or solution. This temperature variation was minimized by cooling the condenser with water supplied from a constant temperature bath.

A small pump was used to circulate cooling water from the constant temperature bath through the condenser. A thermoregulator in the bath was set to activate a three-way solenoid valve in the return water line from the condenser when the temperature rose above $18^{\circ} \mathrm{C}$. in the bath. The system controlled the relation of the flow of water returning directly to the main bath and that which passed through a 1/4-inch tubing in an adjacent icebath before returning to the main bath. By regulating the amount of flow through the tubing in the ice-bath, the temperature in the main bath was controlled to $18 \pm 0.2^{\circ} \mathrm{C}$.

\section{EBULLIOMETER OPERATION}

\section{Sample Preparation and Operating Procedure}

The ebulliometer is operated principally with Freon-113 as the solvent because most of the fluorocarbon compounds of interest are soluble in it. Simple solubility tests for visual clarity are conducted with any new materials to be measured.

In preparation for making a molecular weight determination, approximately $35 \mathrm{~g}$ of Freon-113 is transferred into a syringe and weighed. The probe is removed from the ebulliometer and the Freon-113 is transferred directly from the syringe into the ebulliometer. The syringe is weighed again to obtain the weight of the solvent. The probe is placed in the ebulliometer and the constant temperature water is circulated through the ebilliometer. condenser. The electric heater in the ebulliometer is turned on; the solvent is heated to boiling and maintained at this temperature for about 20 minutes, during which time the system comes to thermal equilibrium. The bridge circuit is balancèd with the "zero adjust."

Approximately $0.3 \mathrm{~g}$ of sample (solute) is used in the determination of molecular weight. The sample is transferred into a tared syringe, it liquid, or onto a tared spatula, if solid, and weighed. The probe is removed from the ebulliometer; the liquid or pelleted sample is injected directly into the ebulliometer. (A solid sample is held by the spatula in the Freon-113 vapors until it is dissolved; the formed solution drains into the ebulliometer.) The syringe or spatula is weighed again to obtain the weight of the sample. 
The probe is returned to the ebulliometer; heat is constantly applied to maintain boiling for about 20 minutes, during which time the system again comes to thermal equilibrium. The bridge circuit is balanced, using the 25-ohm 10-turn measuring potentiometer. The difference in resistance between the two thermistors is determined and converted to difference in temperature (elevation of the boiling point) by applying the calibration constant $\left(0.03268^{\circ} \mathrm{C} . / \mathrm{ohm}\right)$.

Determination of Ebullioscopic Constant for Freon-113

Naphthalene, with a molecular weight of 128.16, was used as the standard solute in the above procedure for measuring the ebullioscopic constant, $\mathrm{K}_{\mathrm{b}}$, for Freon-113 in the thermistorized glass probe system. The constant, $\mathrm{K}_{\mathrm{b}}$, is employed in the following equation (2):

$$
\Delta \mathrm{T}_{\mathrm{b}}=\frac{\mathrm{K}_{\mathrm{b}} \times \text { wt. of solute } \times 1000}{\text { mol wt. of solute } \times \text { wt. of solvent }}
$$

where $\Delta \mathrm{T}_{\mathrm{b}}=$ elevation in boiling point.

Solving for $K_{b}$, using naphthalene solute:

$$
\mathrm{K}_{\mathrm{b}}=\frac{\Delta \mathrm{T}_{\mathrm{b}} \mathrm{x} \cdot \mathrm{mol} \text {. wt. of solute }(128.16) \times \mathrm{wt} \text {. of solvent }}{\text { wt. of solute } \mathrm{x} 1000}
$$

The ebullioscopic constant, $\mathrm{K}_{\mathrm{h}}$, for Freon-113 is $5.198{ }^{\circ} \mathrm{C} . / \mathrm{mole} / 1000 \mathrm{~g}$ solvent. 'l'he individual determinations f'rom which this mean value was established are presented in table II.

TABLE II

EBULLIOSCOPIC CONSTANT FOR FREON-113 DETERMINED WITH THE THERMISTORIZED GLASS PROBE

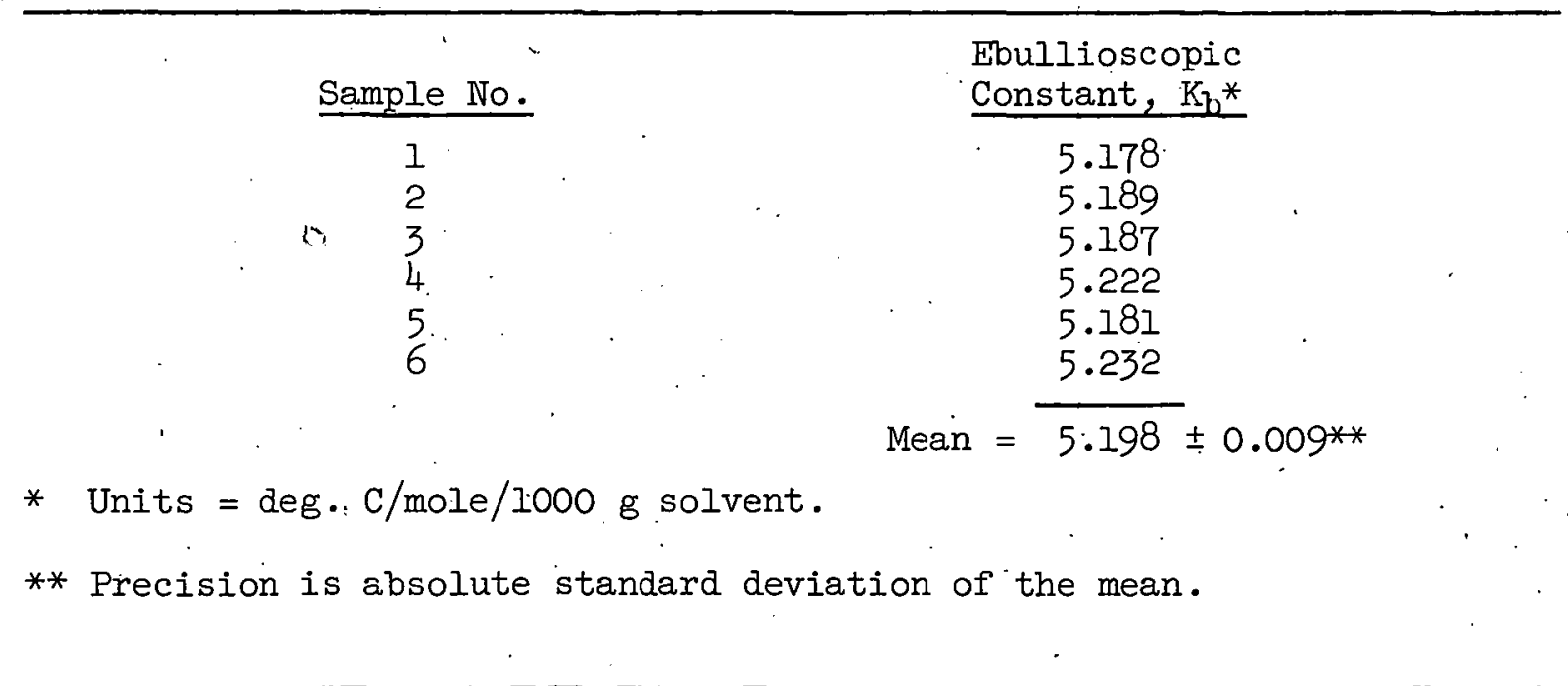


RESULTS

Molecular Weight Determination

The average molecular weight of a tested solute compound, determined in Freon-113, is calculated as follows:

$$
\text { Mol. wt. of solute }=\frac{5.198 \times \text { wt. of solute } \mathrm{x} 1000}{\Delta \mathrm{T}_{\mathrm{b}} \mathrm{x} \text { wt. of solvent }}
$$

The average molecular weight determined for a chlorotrifluoroethylene polymer was 1141. The results of replicate measurements are listed in table III. The absolute standard deviation of a single measurement is \pm 8 , equivalent to a temperature standard deviation of $\pm 0.00030^{\circ} \mathrm{C}$. The data are about 10 times as precise as data obtained for the polymer with the earlier water thermometer system.

TABLE III

REPEATABILITY OF THERMISTORIZED FLUOROTHENE PROBE SYSTEM

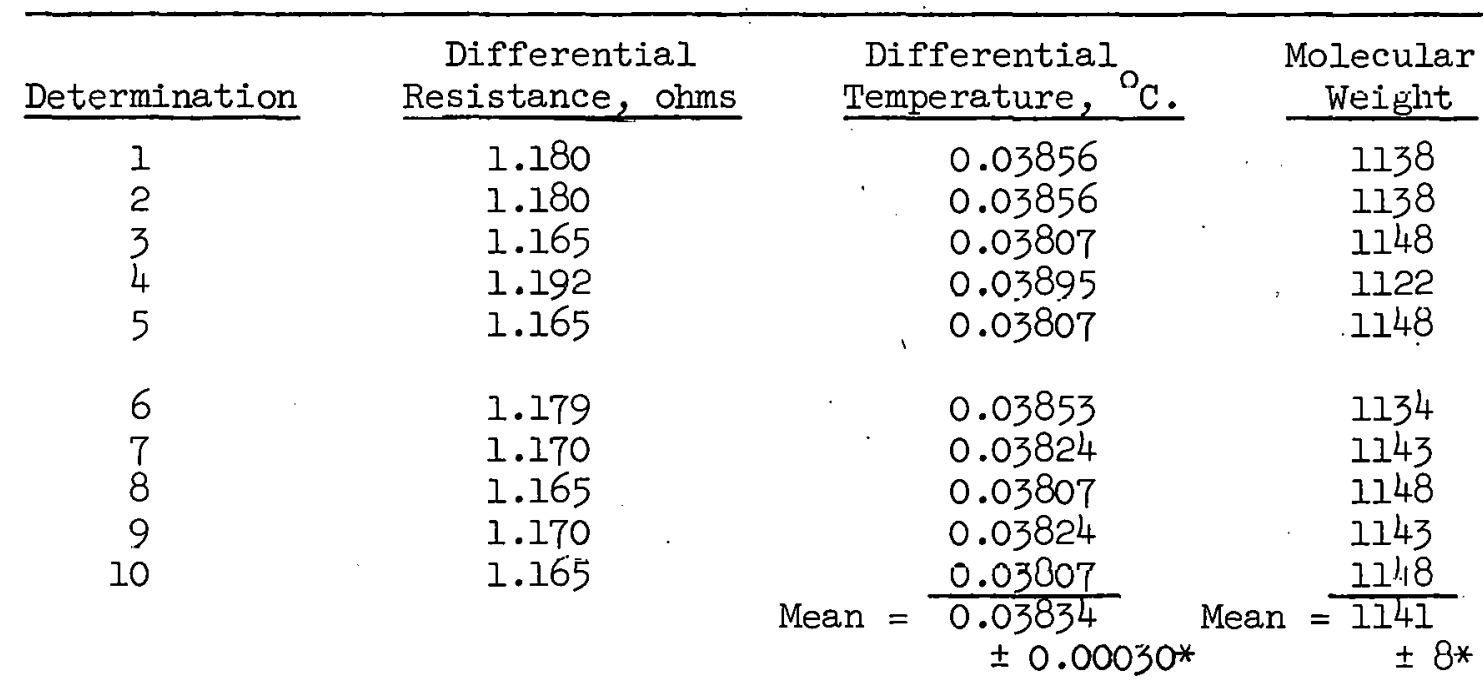

* Precision is absolute'standard deviation of a single measurement.

Thermal Noise Background of Thermistorized System

During the operation of the improved system, the thermal noise background was equivalent to about $\pm 0.00035^{\circ} \mathrm{C}$. This agrees well with the standard deviation of $0.00030^{\circ} \mathrm{C}$. shown in table III. This low background is an improvement of more than tenfold over the $\pm 0.005^{\circ} \mathrm{C}$. noise background of the original thermometer system. The background of $0.005^{\circ} \mathrm{C}$., when applied to molecular weights in the region of 1200 , corresponded to a molecular 
weight variation of approximately ' \pm 150 (note that $\Delta \mathrm{T}_{\mathrm{b}}$ of $0.03834^{\circ} \mathrm{C} . "=$ 1141 mol: wt, table III). The thermal noise background of the new system, $\pm 0.00035^{\circ} \mathrm{C}$, is equivalent to a molecular weight variance of about \pm 10 .

\section{ACKINOWLEDGEMMENTS}

This work was conducted at the request of $\mathrm{C}$. J. King of the Process Development Departments. The authors, R. D. Rivers and W. O. Gentry, wish to express their appreciation for the assistance and encouragement given by their supervisors, R. Aiken of the Chemical Analysis Department and J.. Farquharson of the Instrument Development Department.

\section{BIBLIOGRAPHY}

1. Blackmore, W. R., "Ebulliometry and the Determination of the Molecular Weight of Polymers," Canadian Journal of Chemistry, 37, 1508-26 (1959).

2. Daniels, Farrington, Outline of Physical Chemistry, 3rd Printing, New York, John Wiley and Sons, Inc., 1948, pp. 230-2. 